\title{
Tank 241-AN-107 Corrosion Coupon Labatory Analysis
}

J. B. Duncan Chemelet, Itd., PC

R. P. Anantatmula CH2M Hill Hanford Group, Inc.

Richland, WA 99352

U.S. Department of Energy Contract DE-AC27-99RL14047

\author{
EDT/ECN: $630461 \quad$ UC: NA \\ Cost Center: 7G500 Charge Code: 500464 \\ B\&R Code: EW01 J2030 Total Pages: $2 \$ 7 A 6$
}

Key Words: 241-AN-107, Corrosion Coupon, Steel, Mass loss, ASTM G-1 - 90

\begin{abstract}
To support the corrosion study for Tank 241-AN-107, corrosion coupons consisting of c-rings and pins were removed from four detectors of the corrosion probe retrieved from the tank. The detectors were located as follows: one in the sludge layer, one in the liquid layer, one in the lower head space and the last in the upper head space. ASTM Method G-1 90 was used to determine the amount of corrosion product present.
\end{abstract}

TRADEMARK DISCLAIMER. Reference herein to any specilic commercial product, process, or service by trade name, trademark, manufacturer, or otherwise, does not necesearily conetitute or imply lis endorsement, recommendation, or favoring by the United States Government or any agency thereof or its contractors or subcontractors.

Printed in the United States of America. To obtain coples of this document, contact: Document Control Services, P.O. Box 950, Mailstop H6-08, Richland WA 99352, Phone (509) 372-2420; Fax (509) 376-4989.

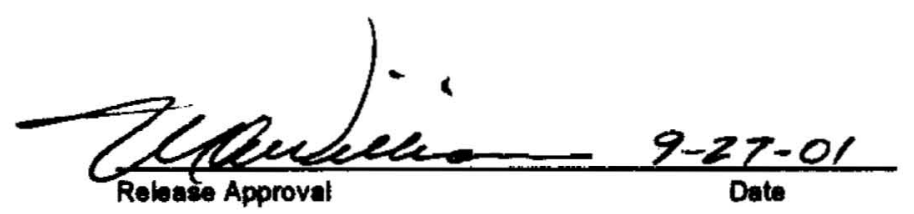

Approved For Public Release

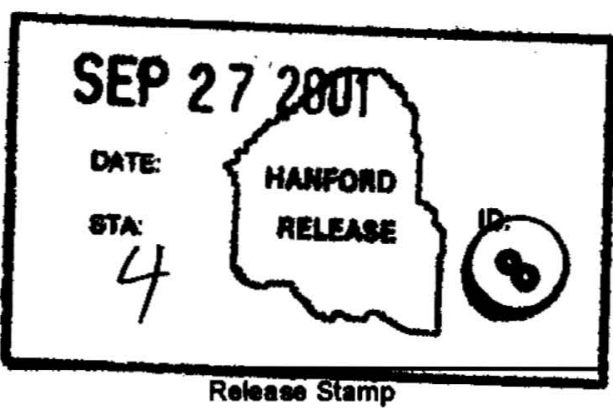

Release Stamp 


\section{Table of Contents}

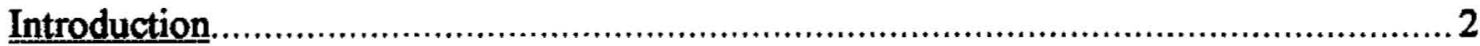

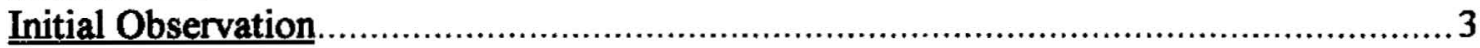

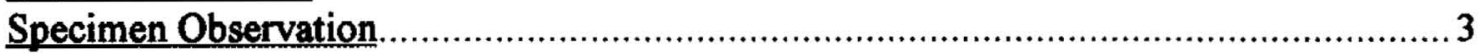

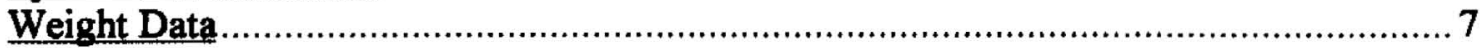

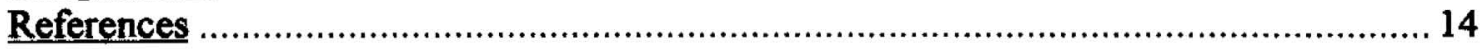

Appendix A Calculation Sheet for Surface Area of C-Ring Plus Bolt and Pin.............. 15

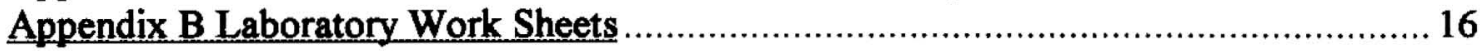

\section{Tables}

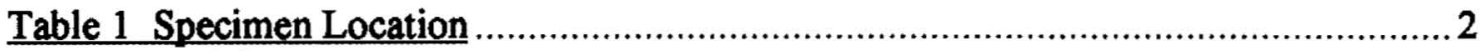

Table 2 Weight Data ........................................................................................ 7

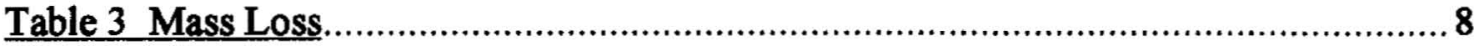

\section{Figures}

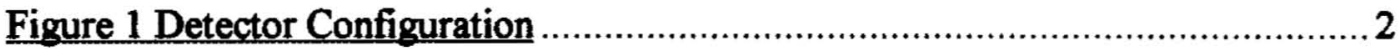

Figures 2-9 Photographs of Exposed C-Rings and Pins.........................

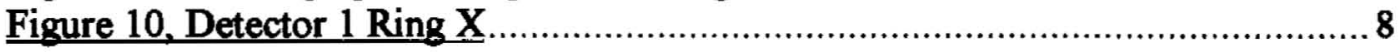

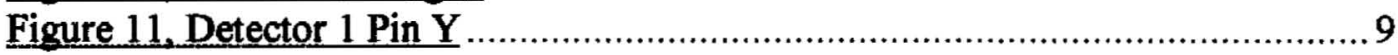

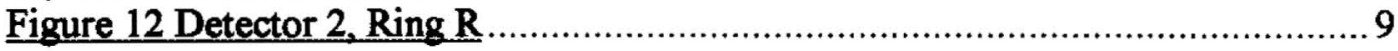

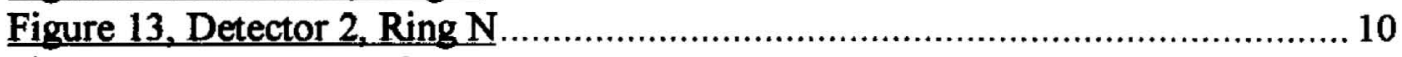

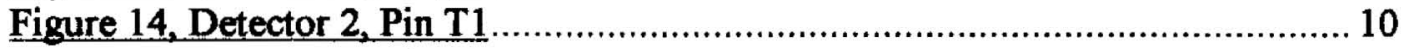

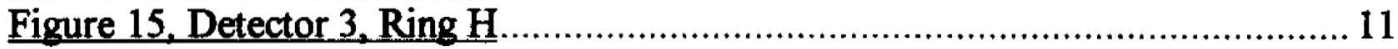

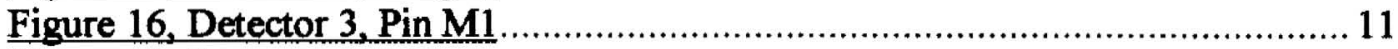

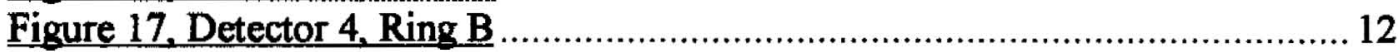

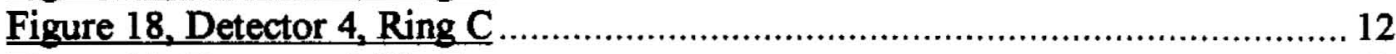

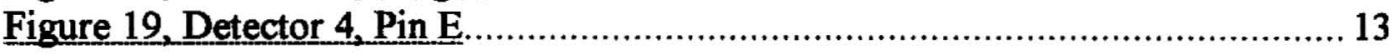

\section{Appendices}

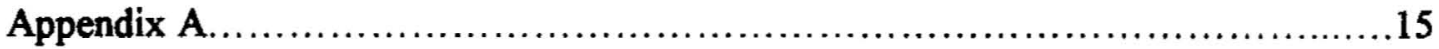

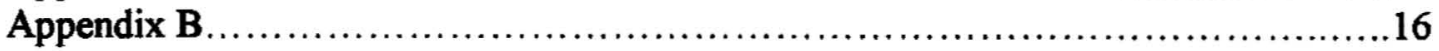


RPP-8920, Rev. 0

\section{Corrosion Test Results}

\section{Introduction}

The corrosion sections were received at 222-S Laboratory on August 9, 2001. Each section was double-wrapped in yellow plastic. The test specimens were separated from each section. The specimen numbers are indicated in Table 1 and detector configuration is shown in Figure 1 (1).

Table 1 Specimen Location

\begin{tabular}{|l|c|c|}
\hline \multicolumn{1}{|c|}{ Specimen } & Detector & Identification \\
\hline Coupon & 1 & $\mathbf{X}$ \\
\hline Pin & 1 & Y \\
\hline Coupon & 2 & R \\
\hline Coupon & 2 & N \\
\hline Pin & 2 & U \\
\hline Coupon & 3 & H \\
\hline Pin & 3 & M1 \\
\hline Coupon & 4 & C \\
\hline Coupon & 4 & B \\
\hline Pin & 4 & E \\
\hline
\end{tabular}

Figure 1 Detector Configuration
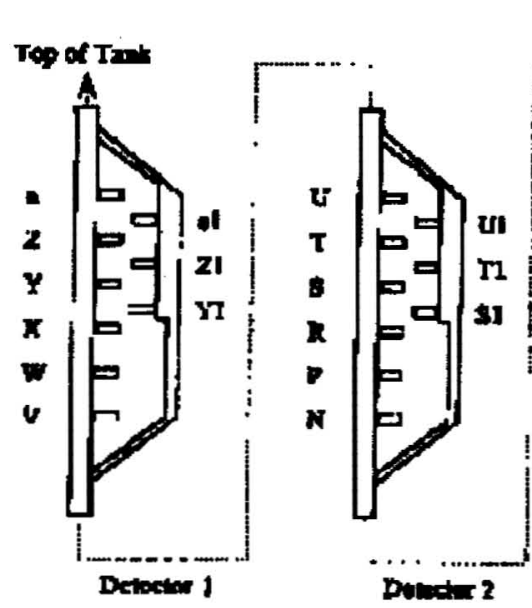

HWF-30-M-TI-816, Ray, O

Dubdar 2

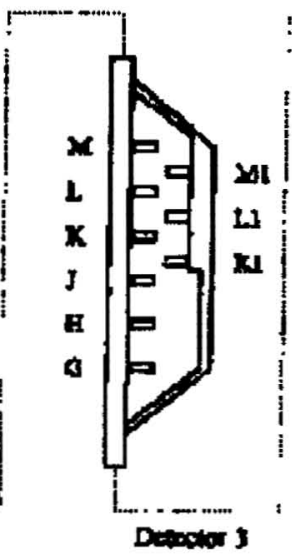

Pritit 1

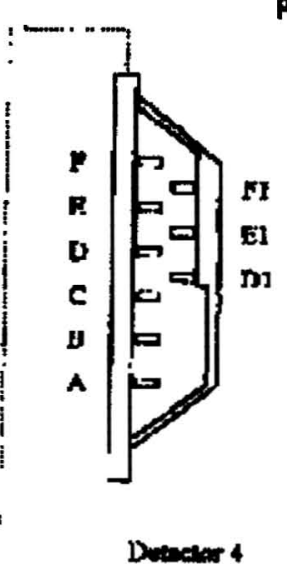




\section{Initial Observation}

The only visible corrosion was on Detector 1 , very slight effects. Of those specimens, the most affected (by visual inspection) coupon and pin were chosen for analysis. The rest of the detectors appeared bright. In fact, the material appeared as new stainless steel.

The O-rings were as new, pliable and no cracking or crazing associated with them.

Photos were taken, as the detectors were unwrapped. Unfortunately, the film broke and there is no photographic record associated with the receipt of the coupons. To ensure a photographic record, digital photos were taken along with emulsion photography during the specimen analysis.

\section{Specimen Observation}

Upon visual inspection, the coupons and pins associated with Detectors 2,3, and 4 appeared as new stainless steel (Figures 2 though 7). However, the specimens associated with Detector 1 did exhibit corrosion (Figures 8 and 9).

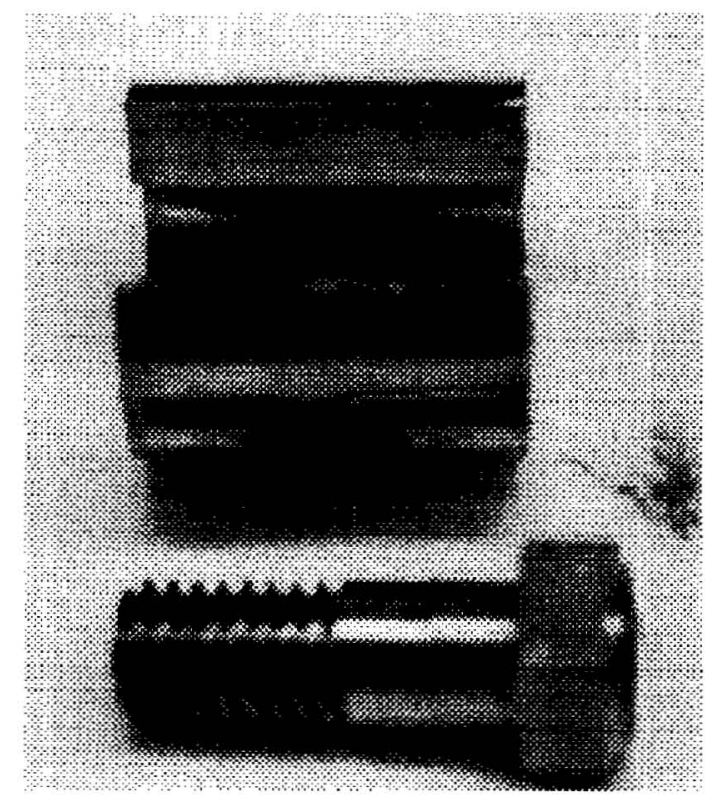

Figure 2 C-Ring Detector 4 (Sludge Layer) 
RPP-8920, Rev. 0

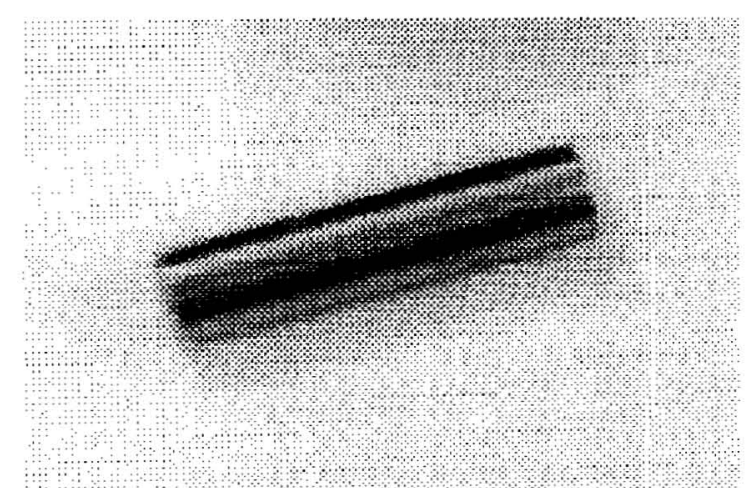

Figure 3 Pin Detector 4 (Sludge Layer)

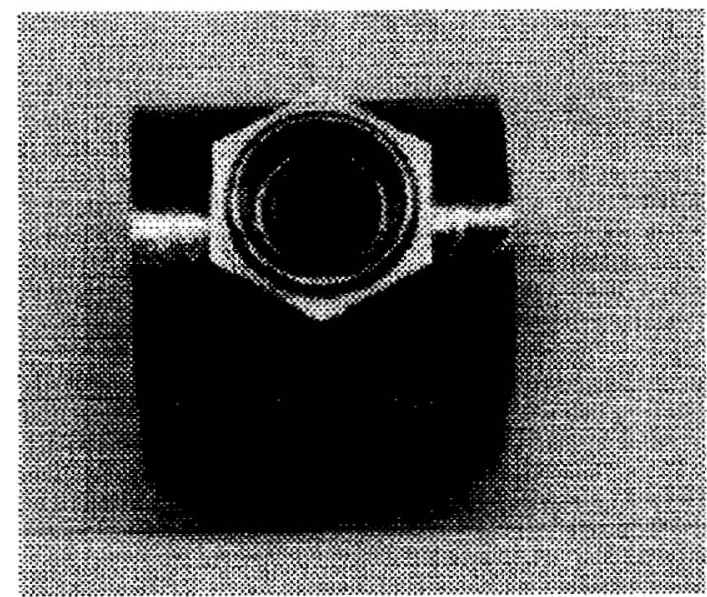

Figure 4 C Ring Detector 3 (Liquid Layer)

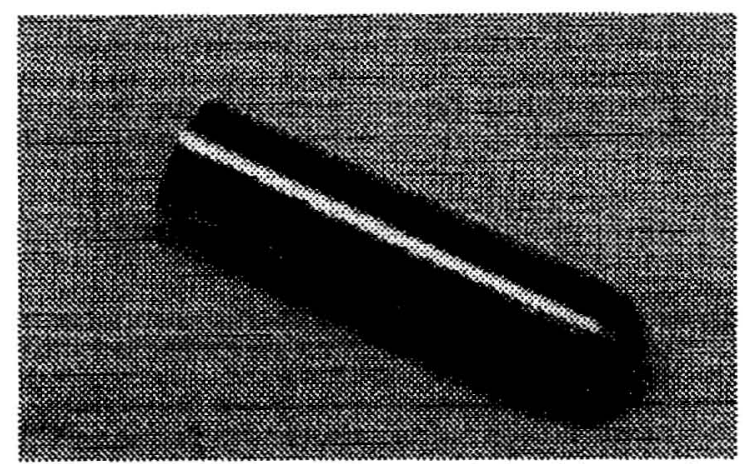

Figure 5 Pin Detector 3 (Liquid Layer) 
RPP-8920, Rev. 0

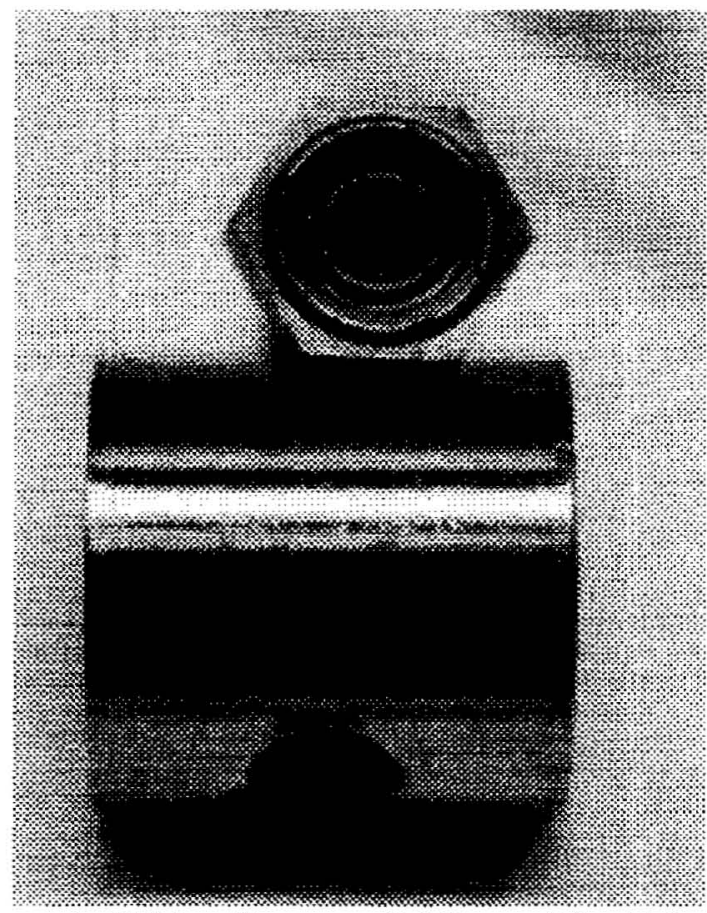

Figure 6 C Ring Detector 2 (Above Liquid Layer)

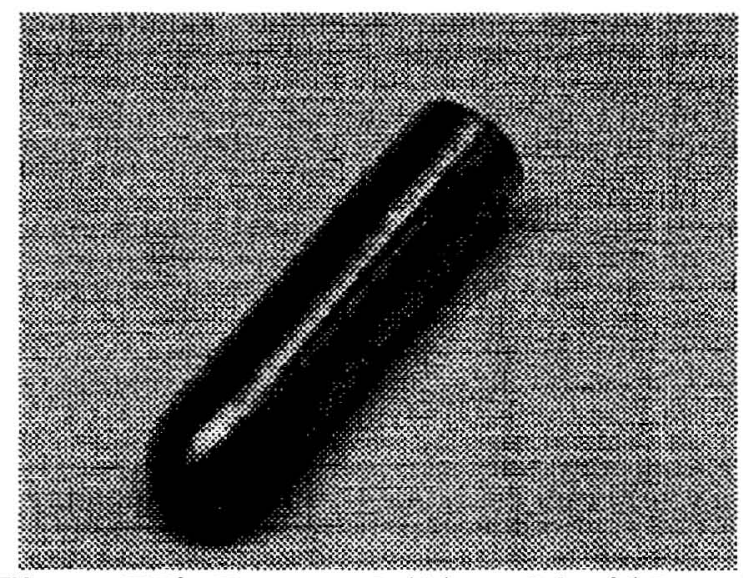

Figure 7 Pin Detector 2 (Above Liquid Layer) 
RPP-8920, Rev. 0

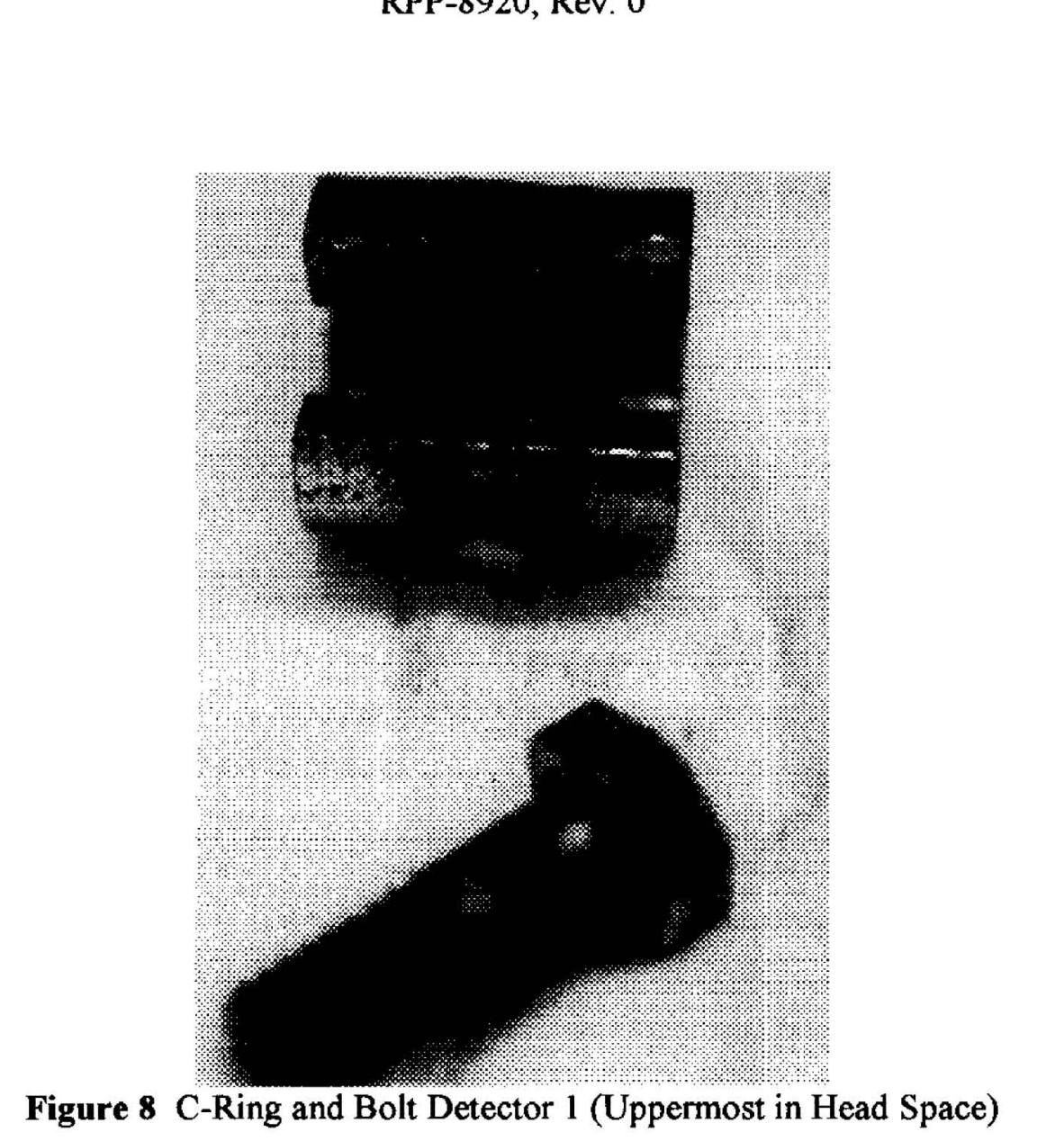

Figure 8 C-Ring and Bolt Detector 1 (Uppermost in Head Space)

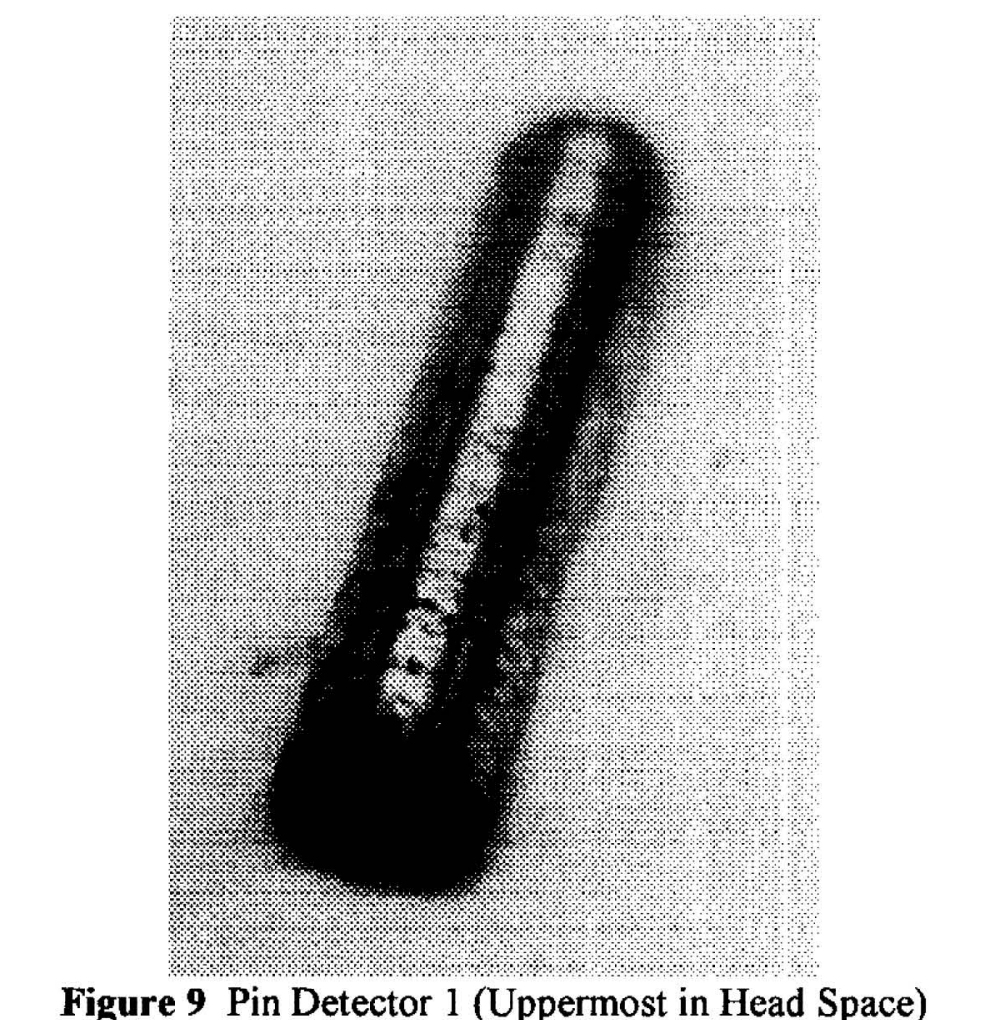

(1)

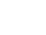

\title{
Figure 9 Pin Detector 1 (Uppermost in Head Space)
}

6

\author{
in
} (n) 


\section{Weight Data}

Table 2 gives the before and after tank exposure mass of the selected specimens. From that data the volume loss is calculated using a density $7.86 \mathrm{~g} / \mathrm{cm}^{3}$ (carbon steel). The exposed surface area of the $\mathrm{C}$-ring and bolt (these were tared together before installing in AN-107) were estimated to be $45 \mathrm{~cm}^{2}\left(35 \mathrm{~cm}^{2} \mathrm{C}\right.$-ring and $10.00 \mathrm{~cm}^{2}$ bolt), and the exposed area of the pin was estimated at $5.0 \mathrm{~cm}^{2}$, Appendix A.

Table 2 Weight Data

\begin{tabular}{|l|l|l|l|l|l|r|}
\hline $\begin{array}{c}\text { Specimen } \\
\text { (Type/Detector) }\end{array}$ & $\begin{array}{c}\text { Tare } \\
\text { Mass } \\
(\mathbf{g})^{\mathbf{n}}\end{array}$ & $\begin{array}{c}\text { Mass } \\
\text { After } \\
\mathbf{A N - 1 0 7} \\
(\mathbf{g})\end{array}$ & $\begin{array}{c}\text { Mass } \\
\text { Difference } \\
(\mathbf{g})\end{array}$ & $\begin{array}{c}\text { Volume } \\
\text { Loss } \\
\mathbf{( c m}^{\mathbf{3}} \mathbf{)}\end{array}$ & $\begin{array}{c}\text { Surface } \\
\text { Area } \\
\mathbf{( c m}^{\mathbf{2}} \mathbf{)}\end{array}$ & $\begin{array}{c}\text { Mil of } \\
\text { material } \\
\text { Removed }\end{array}$ \\
\hline X (C-ring/1) & 74.3170 & 74.3058 & 0.0112 & $1.42 \mathrm{E}-03$ & 45 & 0.0124 \\
\hline Y (Pin/1) & 4.9734 & 4.9327 & 0.0407 & $5.18 \mathrm{E}-03$ & 5.0 & 0.4078 \\
\hline R (C-ring/2) & 72.9774 & 72.9451 & 0.0323 & $4.11 \mathrm{E}-03$ & 45 & 0.0359 \\
\hline N (C-ring/2) & 74.3109 & 74.2255 & 0.0854 & $1.09 \mathrm{E}-02$ & 45 & 0.0954 \\
\hline T1 (Pin/2) & 5.1834 & 5.1767 & 0.0067 & $8.52 \mathrm{E}-04$ & 5.0 & 0.0671 \\
\hline H(C-ring/3) & 71.9258 & 71.9047 & 0.0211 & $2.68 \mathrm{E}-03$ & 45 & 0.0235 \\
\hline M1 (Pin/3) & 5.2468 & 5.2402 & 0.0066 & $8.40 \mathrm{E}-04$ & 5.0 & 0.0066 \\
\hline B (C-ring/4) & 72.6529 & 72.6363 & 0.0166 & $2.11 \mathrm{E}-03$ & 45 & 0.0184 \\
\hline C (C-ring/4) & 73.4843 & 73.4756 & 0.0087 & $1.11 \mathrm{E}-03$ & 45 & 0.0097 \\
\hline E (Pin/4) & 5.3126 & 5.3121 & 0.0005 & $6.36 \mathrm{E}-05$ & 5.0 & 0.0050 \\
\hline
\end{tabular}

${ }^{\mathrm{a}}$ Edgemon

The surface area for the $\mathrm{C}$-ring and bolt was based on dimensions given in Drawing Number 0007-HEF-117A (HiLine Engineering). For the calculations, the assumptions that the bolt threads were negligible for surface area contributions and that part of the bolt covered by the $\mathrm{C}$-ring was not exposed to $\mathrm{AN}-107$ chemistry. The pin was estimated by measurement of a control specimen. The pin estimate was conservative in that the control specimen was like the pin in Figure 3.

Table 3 shows the mass loss after digestion with dibasic ammonium citrate using ASTM method G-1 (2). The digestion solution ( $0.88 \mathrm{M})$ was changed after each detector. This allowed digestion to occur with several orders of magnitude difference between the molarity of the digested material versus the molarity of the digestion solution.

Instrument technicians from the 222-S Laboratory maintenance group calibrated the balance before the work ensued. Furthermore, the balance was measured against check weights during the course of the four-day laboratory effort. 
RPP-8920, Rev. 0

Table 3 Mass Loss

\begin{tabular}{|c|c|c|}
\hline $\begin{array}{c}\text { Specimen } \\
\text { (Type/Detector) }\end{array}$ & $\begin{array}{l}\text { Beginning } \\
\text { Mass } \\
\text { (g) }\end{array}$ & $\begin{array}{c}\text { Mass loss at inflection } \\
\text { point } \\
\text { (g) }\end{array}$ \\
\hline$X(\bar{C}$-ring $/ 1)$ & 74.3170 & 0.367 \\
\hline $\mathrm{Y}(\mathrm{Pin} / 1)$ & 4.9734 & 0.038 \\
\hline $\mathrm{R}(\mathrm{C}$-ring/2) & 72.9774 & 0.089 \\
\hline $\mathrm{N}$ (C-ring/2) & 74.3109 & 0.098 \\
\hline $\mathrm{T} 1(\mathrm{Pin} / 2)$ & 5.1834 & 0.028 \\
\hline $\mathrm{H}(\mathrm{C}$-ring $/ 3)$ & 71.9258 & 0.089 \\
\hline $\mathrm{M} 1(\mathrm{Pin} / 3)$ & 5.2468 & 0.008 \\
\hline B (C-ring/4) & 72.6529 & 0.045 \\
\hline $\mathrm{C}(\mathrm{C}$-ring/4) & 73.4843 & 0.068 \\
\hline $\mathrm{E}(\mathrm{Pin} / 4)$ & 5.3126 & 0.025 \\
\hline
\end{tabular}

${ }^{a}$ Taken from Figures 10 - 19 .

Figures $10-19$ indicate the response and inflection point for each specimen. Although
not confirmed, it is thought that the data exhibited in figures 17 and 18 is due to the effect
of the soak solution on the C-ring metal, that is, corrosion was practically non-existent on
those specimens.

Figures $10-19$ indicate the response and inflection point for each specimen. Although
not confirmed, it is thought that the data exhibited in figures 17 and 18 is due to the effect
of the soak solution on the C-ring metal, that is, corrosion was practically non-existent on
those specimens.

Figures $10-19$ indicate the response and inflection point for each specimen. Although
not confirmed, it is thought that the data exhibited in figures 17 and 18 is due to the effect
of the soak solution on the C-ring metal, that is, corrosion was practically non-existent on
those specimens.

Figures $10-19$ indicate the response and inflection point for each specimen. Although
not confirmed, it is thought that the data exhibited in figures 17 and 18 is due to the effect
of the soak solution on the C-ring metal, that is, corrosion was practically non-existent on
those specimens.

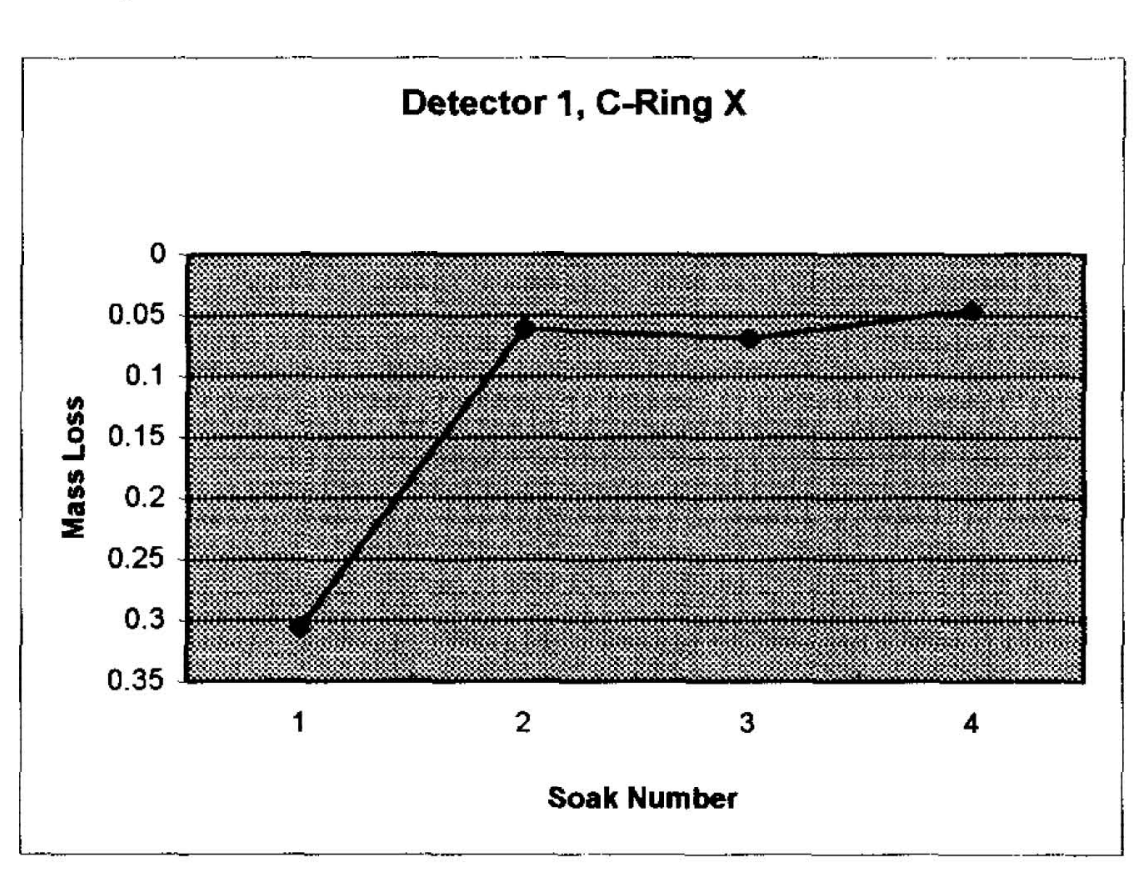

Figure 10, Detector 1 Ring X 
RPP-8920, Rev. 0

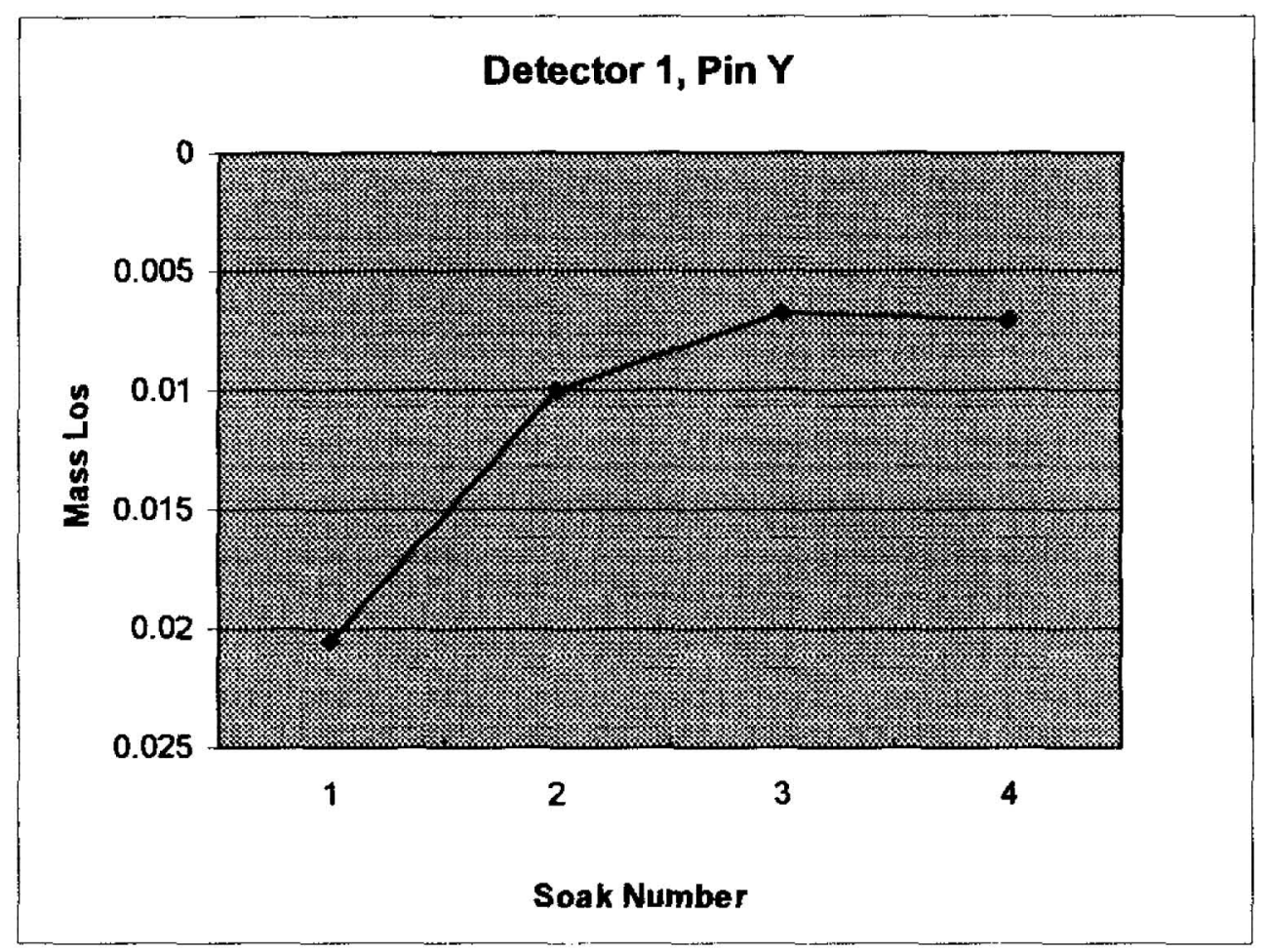

Figure 11, Detector 1 Pin Y

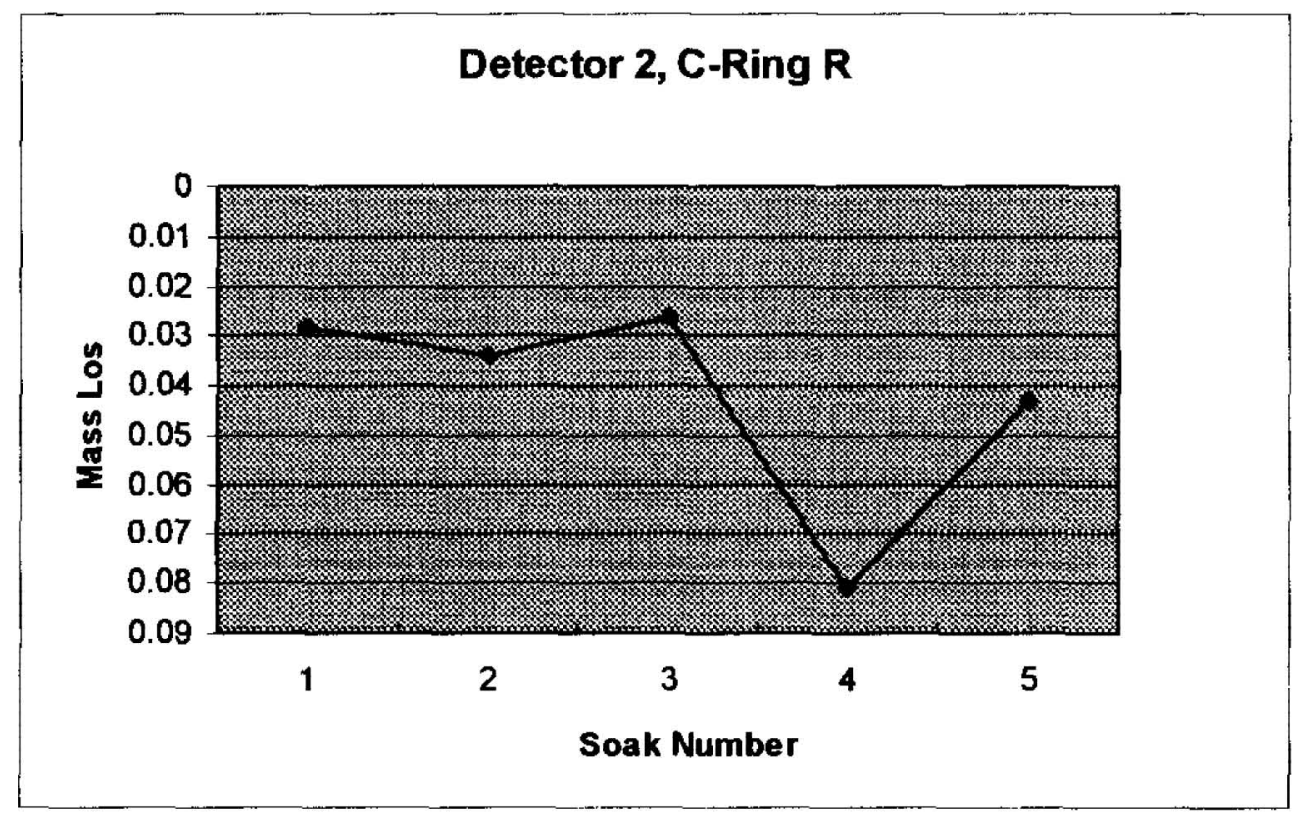

Figure 12 Detector 2, Ring $\mathbf{R}$

\author{
Fire 12 Detector 2, Ring $R$
}


RPP-8920, Rev. 0

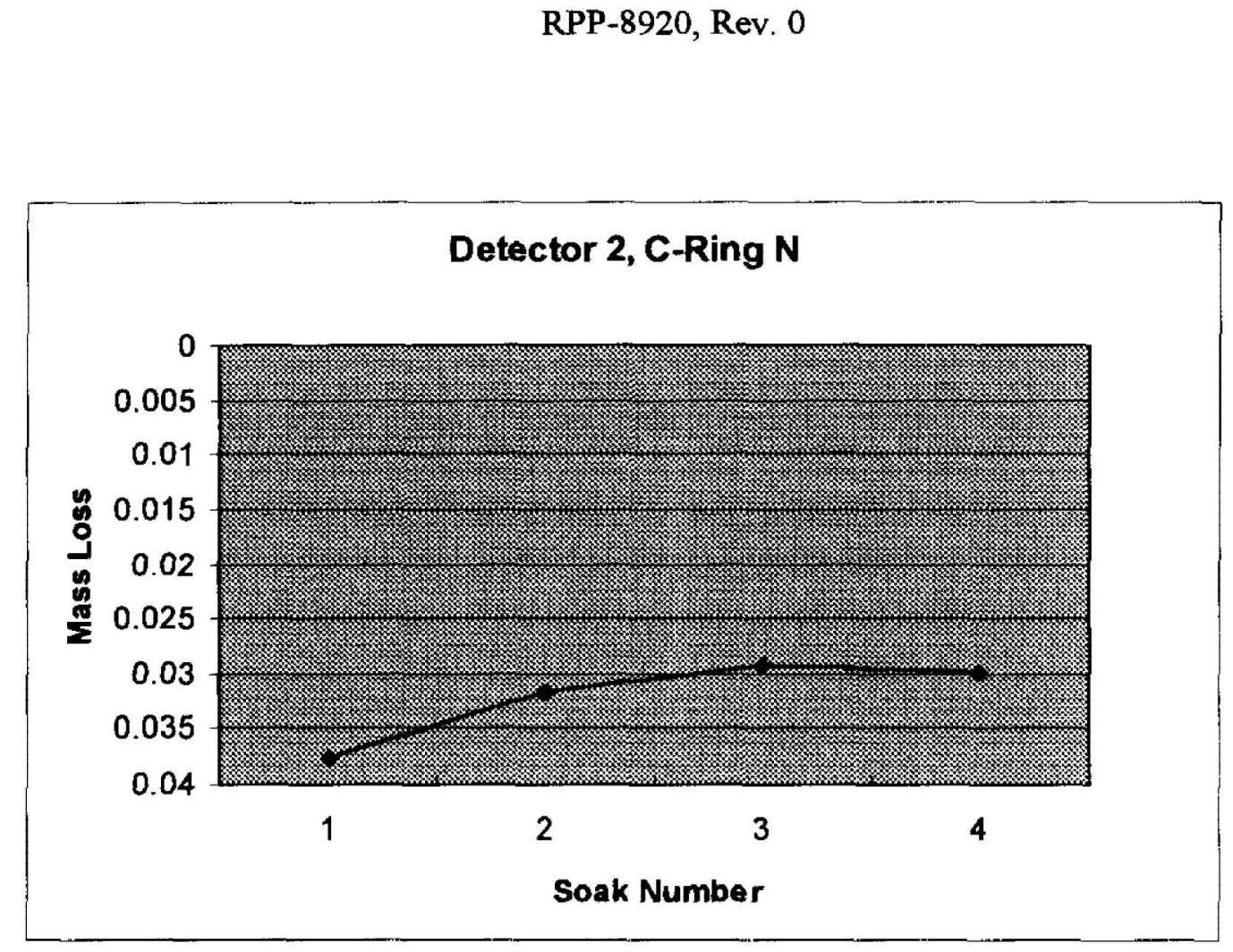

Figure 13, Detector 2, Ring N

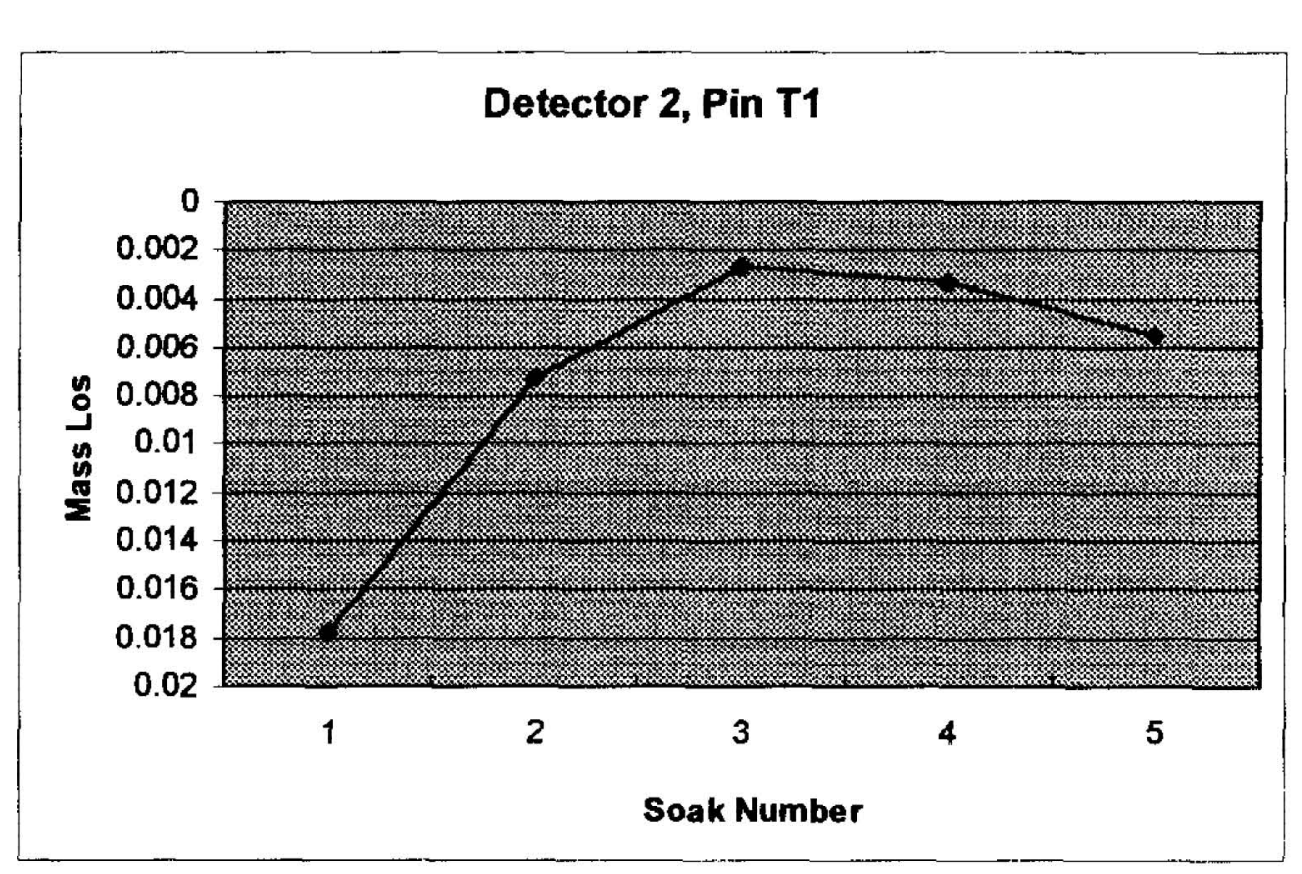

\section{Figure 14, Detector 2, Pin T1}


RPP-8920, Rev. 0

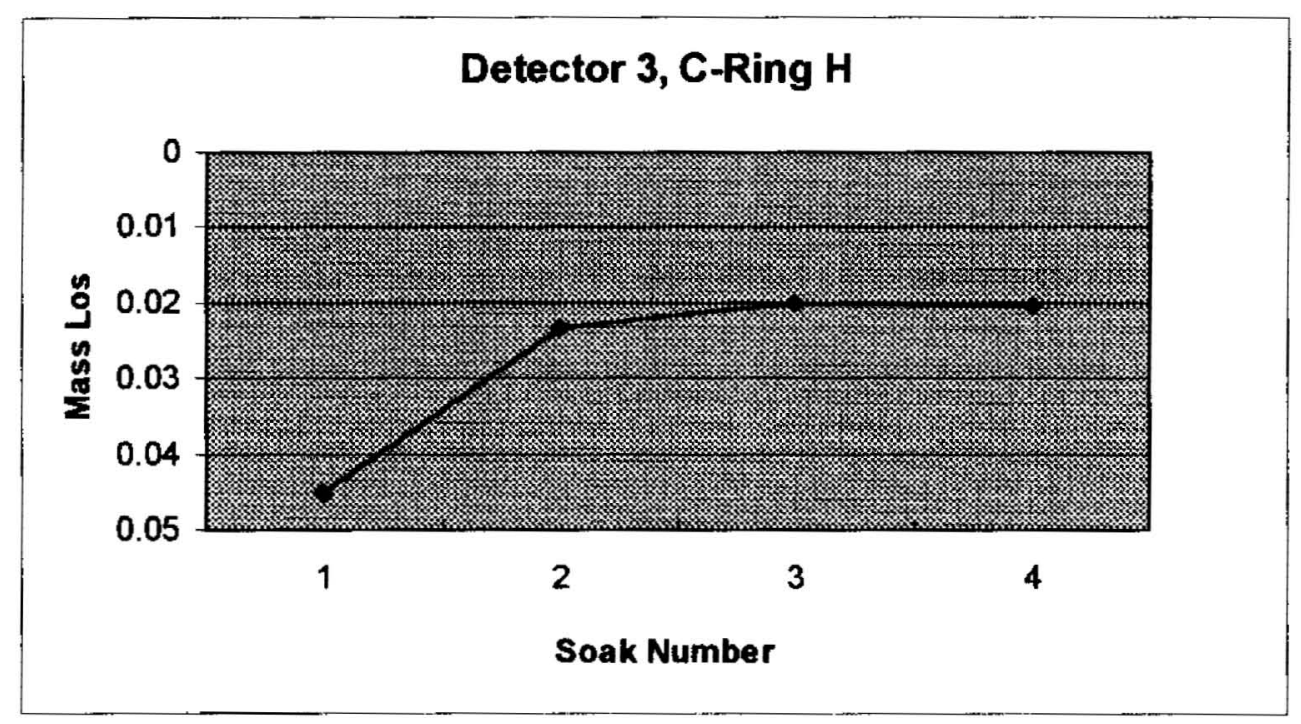

Figure 15, Detector 3, Ring $H$

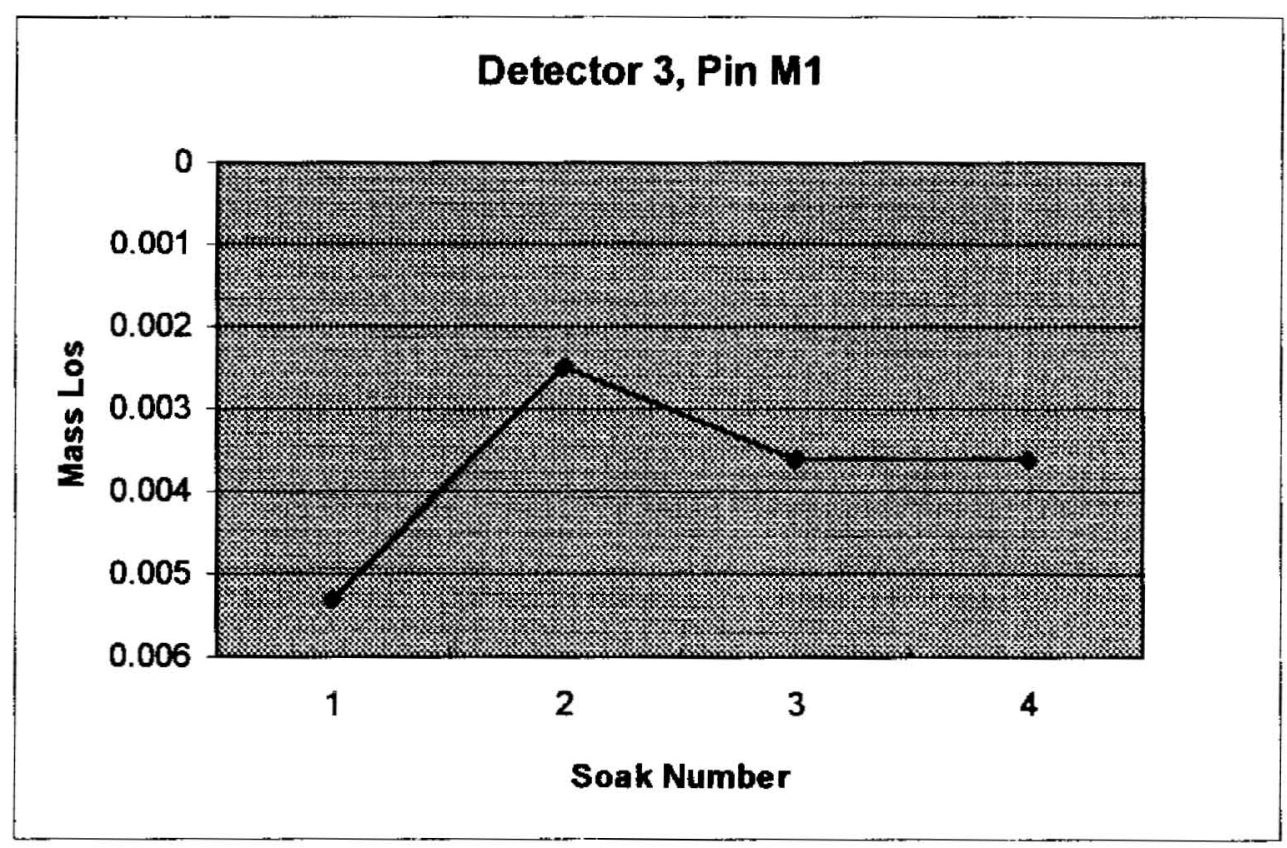

Figure 16, Detector 3, Pin M1 
RPP-8920, Rev. 0

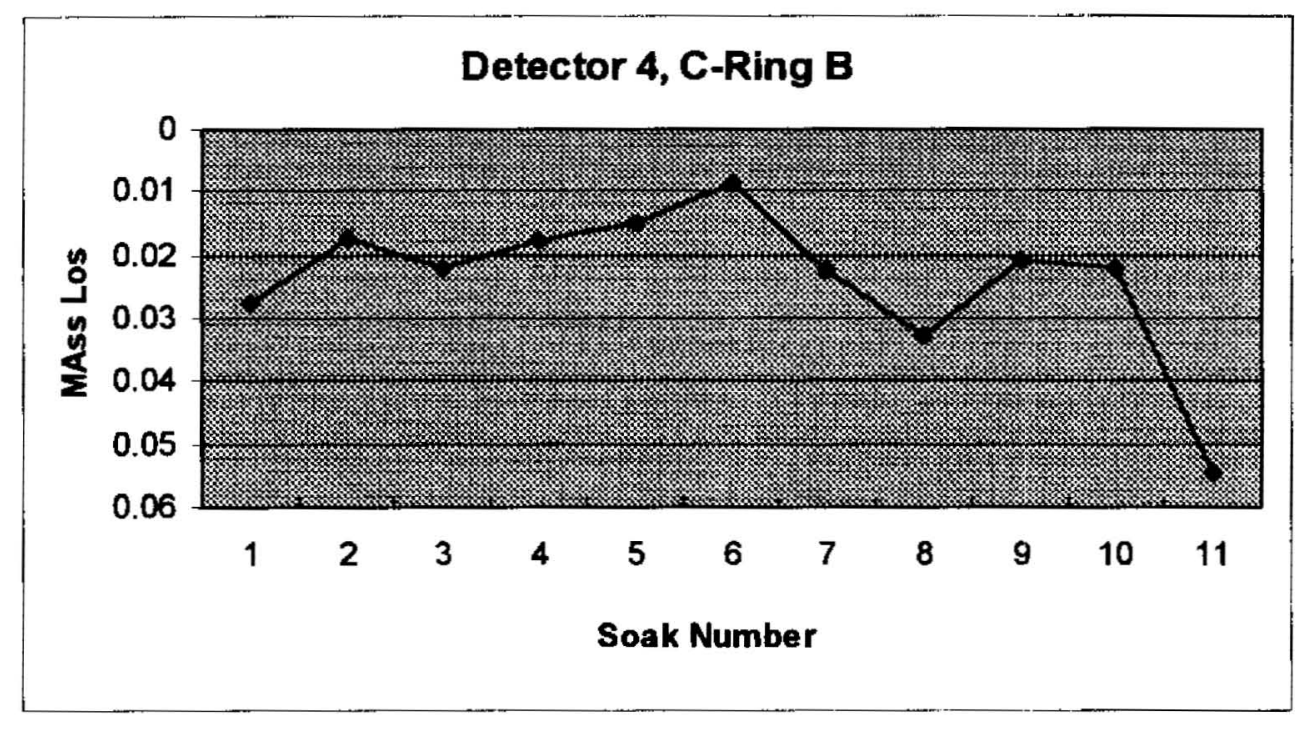

Figure 17, Detector 4, Ring $B$

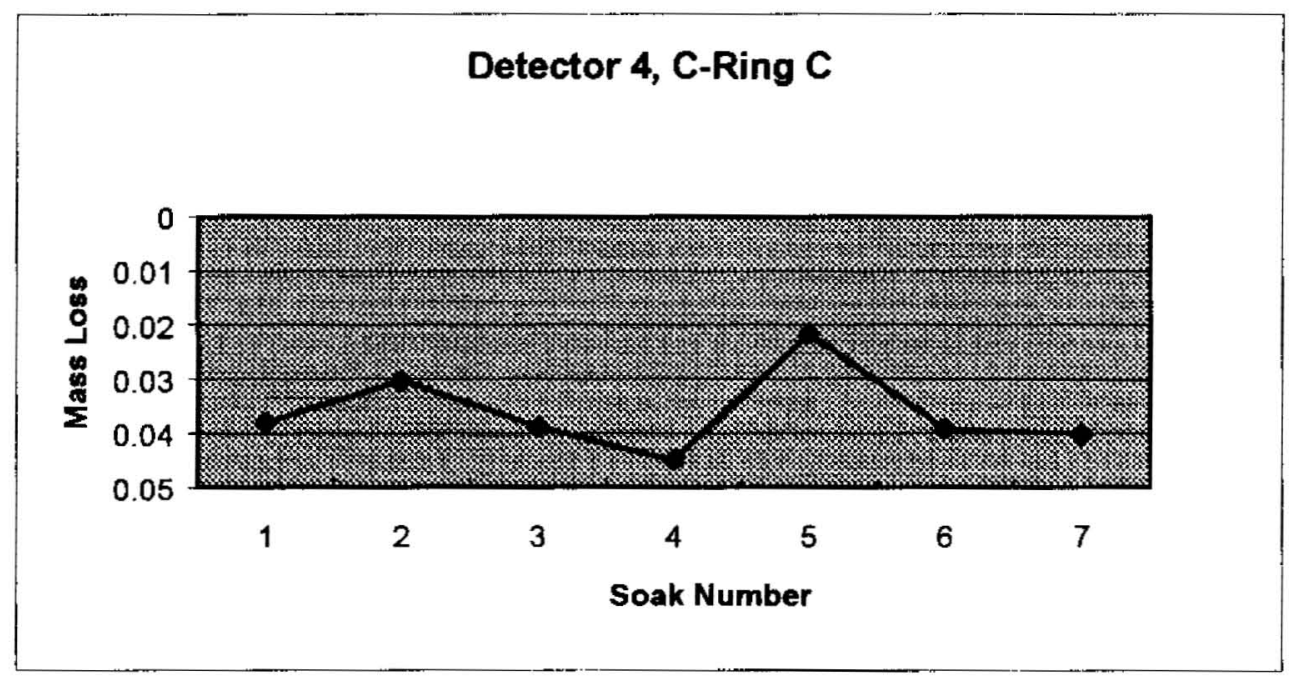

Figure 18, Detector 4, Ring C 


$$
\text { RPP-8920, Rev. } 0
$$

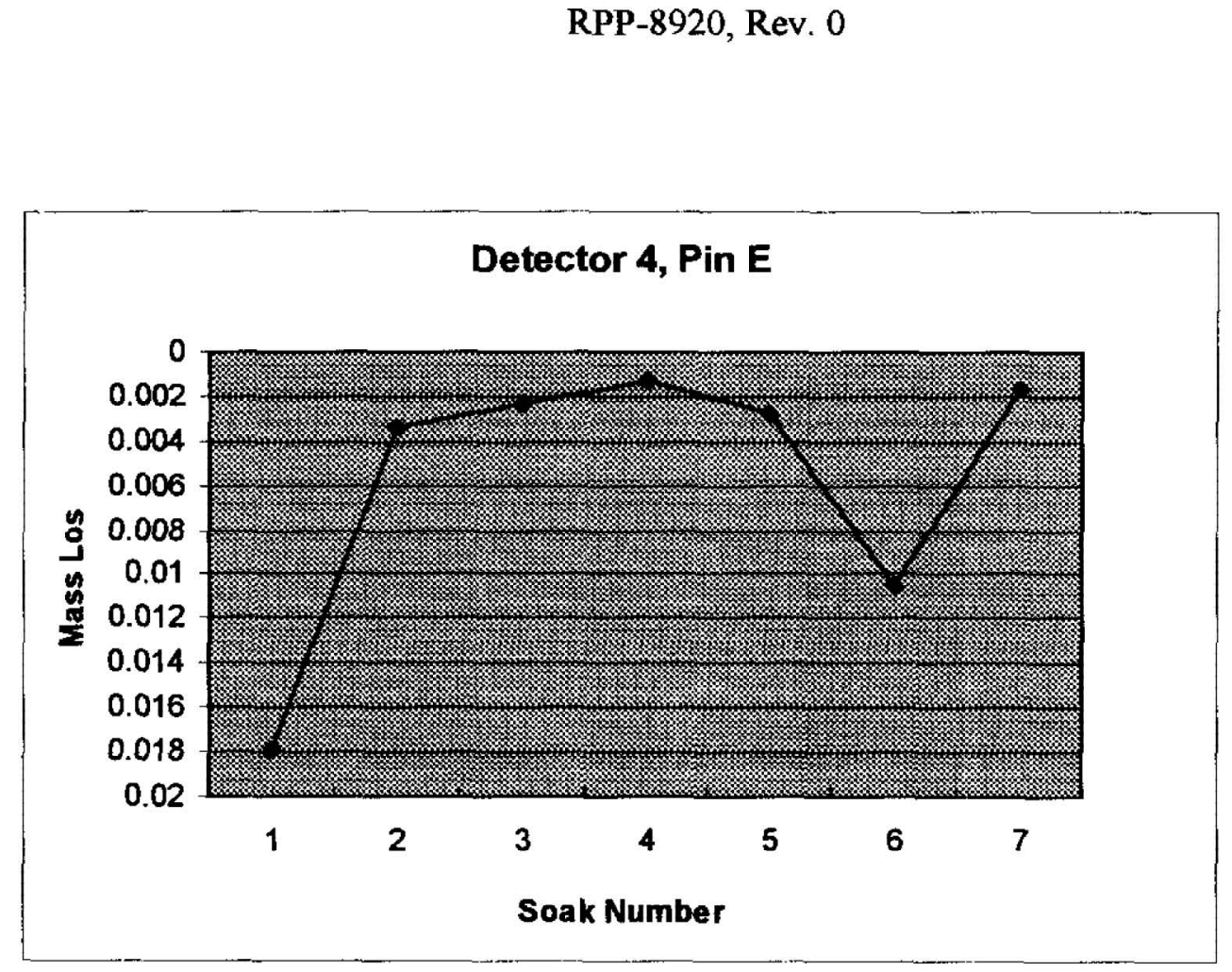

Figure 19, Detector 4, Pin E

\section{(2)}

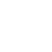


RPP-8920, Rev. 0

\section{References}

1. Edgemon, G. L., “241-AN-107Corrosion Probe Electrode Weights”, HNF-SDWM-TI-816, Rev. 0, August, 1997.

2. "Standard Practice for Preparing, Cleaning, and Evaluating Corrosion Test Specimens", Designation: G-1 - 90 (Reapproved 1999), ASTM, 2000. 
Page 18 of 29 of $\mathrm{D} 8841784$

RPP-8920,

GHG 8840, Rev. 0

Appendix A Calculation Sheets for Surface Area of C-Ring Plus Bolt and Pin

EXPOSE AREA OF CARING:

To be conservative, assumed a $60^{\circ}$ sector removed from right circular cylinder with dimensions "long $\times \frac{1}{2}$ "ID. $\times 10.0$. to make a C- Ring coupon.

Total Surface Area $(S A)=S A$ of Top $+S A$ of Bottom $+S A$ of inside of $0.5^{\prime \prime}$ dir cophinder + SA of out side of 1.0" cylinder $+5 A$ of exposed rectangle w faces $-\frac{1}{6}$ of cylinder $5 A$ cut out

$=\frac{5}{6}[$ cylinder $5 A]+5 A$ of exposed faces

$$
\begin{aligned}
=5 / 6 & {\left[2 \times \frac{\pi\left(1^{2}-0.5^{2}\right)}{4}+\pi \times 0.5 \times 1+\pi \times 1 \times 1\right] \mathrm{in}^{2} } \\
& +2 \times 1 \times \frac{1}{4} \mathrm{in}^{2}
\end{aligned}
$$$$
=34.895 \mathrm{~cm}^{2}
$$

EXPOSED AREA OF BOLT:

The exposed areas are $O$ Both sides of hexagonal head and (2) Cylindrical bet t stem on inside of CARing.

(1) Hexagram head sA $=2 \times 6 \times \frac{1}{2} \times \frac{5}{16} \times \frac{5}{16} \times \sin 60^{\circ}=0.5074 \mathrm{in}^{2}=3.2738 \mathrm{~cm}^{2}$

plus Rectangular sides $S_{A}=6 \times \frac{5}{16} \times \frac{1}{4}=0.4688 \mathrm{in}^{2}=3.0242 \mathrm{~cm}^{2}$

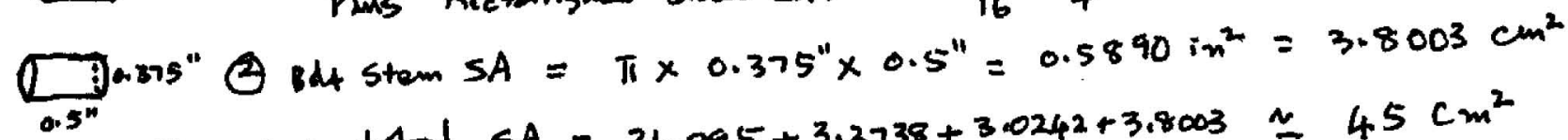

These fore total $S A=34.895+3.2738+3.0242+3.8003 \simeq 45 \mathrm{~cm}^{2}$

Exposed Area of Pin:

$$
\begin{aligned}
& \text { The exposed SA of Pin }=\pi \times \frac{1^{\prime \prime}}{4} \times 1^{\prime \prime}+\pi \times\left(\frac{10}{8}\right)^{2} \\
& =0.8345 \mathrm{in}^{2} \\
& \simeq 5 \mathrm{~cm}^{2}
\end{aligned}
$$

15 
RPP-8920, Rev. 0

Appendix B Laboratory Work Sheets 


\begin{tabular}{|c|c|c|c|c|c|}
\hline $\begin{array}{c}\text { Coupon } \\
\text { Identification } \\
\text { Detector }-11 \\
\text { Pin: } 14\end{array}$ & $\begin{array}{c}\text { Weight } \\
\text { Before } \\
\text { placing in } \\
\text { Soak } \\
\text { Solution } \\
2\end{array}$ & $\begin{array}{c}\text { Time in } \\
\text { Soak } \\
\text { Solution } \\
\\
3\end{array}$ & $\begin{array}{l}\text { Temperature } \\
\text { of Solution }\end{array}$ & $\begin{array}{c}\text { Weight } \\
\text { after } \\
\text { Solution } \\
\text { Soak } \\
5\end{array}$ & $\begin{array}{c}\text { Photograph } \\
\text { Identification } \\
\text { (Magnification } \\
\text { and Distance) } \\
6\end{array}$ \\
\hline 1 & 4.9327 & 10 & $86^{\circ} \mathrm{C}$ & 4.9122 & $19-20+2$ \\
\hline 2 & 4.9122 & 10 & $86^{\circ} \mathrm{C}$ & 4.9022 & \\
\hline 3 & 4.9022 & 10 & $89 \circ \mathrm{C}$ & 4.8256 & \\
\hline 4 & 4.8955 & 10 & $90^{\circ} \mathrm{C}$ & 4.8885 & \\
\hline 5 & & & & & 414 \\
\hline & & & & & \\
\hline & & & & & \\
\hline & & & & & \\
\hline & & & & & \\
\hline & & & & & \\
\hline & & & & & $\therefore$ \\
\hline & & & & & \\
\hline & & & & & \\
\hline & & & & & \\
\hline & & & & & \\
\hline & & & & & \\
\hline & & & & & \\
\hline & & & & & \\
\hline & & & & & \\
\hline & & & & & \\
\hline & & & & & \\
\hline & & & & & \\
\hline & & & & & \\
\hline & & & & & \\
\hline & & & & & \\
\hline & & & & & \\
\hline & & & & & \\
\hline & & & & & \\
\hline & & & & & \\
\hline & & & & & \\
\hline & & & & & \\
\hline
\end{tabular}




\begin{tabular}{|c|c|c|c|c|c|}
\hline $\begin{array}{c}\text { Coupon } \\
\text { Identification } \\
\text { Detector } \not^{\prime} 1 \\
\text { C-Ring: } \mathbb{X}^{-1} \\
1 \\
\end{array}$ & $\begin{array}{l}\text { Weight } \\
\text { Before } \\
\text { placing in } \\
\text { Soak } \\
\text { Solution } \\
2 \\
\end{array}$ & $\begin{array}{c}\text { Time in } \\
\text { Soak } \\
\text { Solution } \\
\\
3 \\
\end{array}$ & $\begin{array}{l}\text { Temperature } \\
\text { of Solution }\end{array}$ & 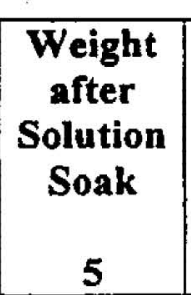 & $\begin{array}{c}\text { Photograph } \\
\text { Identification } \\
\text { (Magnification } \\
\text { and Distance) } \\
6 \\
\end{array}$ \\
\hline 1 & 74.3058 & 10 & $86^{\circ} \mathrm{C}$ & $7 \overline{7.9995}$ & $19+206$ \\
\hline 2 & 73.9995 & 10 & $86^{\circ} \mathrm{C}$ & 73,9388 & \\
\hline 3 & 73.9588 & 10 & $89^{\circ} \mathrm{C}$ & 73.8705 & \\
\hline 4 & 73.8705 & 10 & $90{ }^{\circ} \mathrm{C}$ & 73.8254 & \\
\hline 5 & 73.8254 & & & & \\
\hline & & & & & 473 湆 \\
\hline & & & & & $41572 \pi$ \\
\hline & & & & & \pm 161000 \\
\hline & & & & & \\
\hline & & & & & \\
\hline & & & & & \\
\hline & & & & & $=$ \\
\hline & & & & & \\
\hline & & & & & \\
\hline & & & & & \\
\hline & & & & & \\
\hline & & & & & \\
\hline & & & & & \\
\hline & & & & & \\
\hline & & & & & \\
\hline & & & & & \\
\hline & & & & & \\
\hline & & & & & \\
\hline & & & & & \\
\hline & & & & & \\
\hline & & & & & \\
\hline & & & & & \\
\hline & & & & & \\
\hline & & & & & \\
\hline & & & & & \\
\hline & & & & & \\
\hline & & & & & \\
\hline & & & & & \\
\hline & & & & & \\
\hline
\end{tabular}




\begin{tabular}{|c|c|c|c|c|c|c|}
\hline $\begin{array}{c}\text { Coupon } \\
\text { Identification } \\
\text { Detector }{ }_{2} \\
\text { Pin: }\end{array}$ & $\begin{array}{c}\text { Weight } \\
\text { Before } \\
\text { placing in } \\
\text { Soak } \\
\text { Solution } \\
2 \\
\end{array}$ & $\begin{array}{c}\begin{array}{c}\text { Time in } \\
\text { Soak } \\
\text { Solution }\end{array} \\
3 \\
\end{array}$ & $\begin{array}{l}\text { Temperature } \\
\text { of Solution }\end{array}$ & $\begin{array}{c}\text { Weight } \\
\text { after } \\
\text { Solution } \\
\text { Soak } \\
5 \\
\end{array}$ & $\begin{array}{c}\text { Photograph } \\
\text { Identification } \\
\text { (Magnification } \\
\text { and Distance) } \\
6 \\
6\end{array}$ & \multirow{32}{*}{$\begin{array}{l}0.0171 \\
0.0073 \\
0.0027 \\
0.0033 \\
0.0053\end{array}$} \\
\hline 1 & 5. 1767 & 10 & $88 c$ & 5,1590 & $452-104$ & \\
\hline 2 & 5.1590 & 10 & $86 C$ & 5.1517 & & \\
\hline 3 & 5,1517 & 10 & $88 c$ & 5.1490 & & \\
\hline 4 & 5.1490 & 10 & $87 C$ & 5.1457 & & \\
\hline 5 & 5,1457 & 10 & $89 c$ & $5: 1402$ & $17+18$ & \\
\hline & & & & & & \\
\hline & & & & & & \\
\hline & & & & & & \\
\hline & & & & & & \\
\hline & & & & & & \\
\hline & & & & & & \\
\hline & & & & & $\therefore$ & \\
\hline & & & & & & \\
\hline & & & & & & \\
\hline & & & & & & \\
\hline & & & & & & \\
\hline & & & & & & \\
\hline & & & & & & \\
\hline & & & & & & \\
\hline & & & & & & \\
\hline & & & & & & \\
\hline & & & & & & \\
\hline & & & & & & \\
\hline & & & & & & \\
\hline & & & & & & \\
\hline & & & & & & \\
\hline & & & & & & \\
\hline & & & & & & \\
\hline & & & & & & \\
\hline & & & & & & \\
\hline & & & & & & \\
\hline
\end{tabular}
$\therefore \quad$ RPP-8920, ReVO 


\begin{tabular}{|c|c|c|c|c|c|}
\hline $\begin{array}{c}\text { Coupon } \\
\text { Identification } \\
\text { Detector } 2 \\
\text { C-Ring: } N^{2} \\
1\end{array}$ & $\begin{array}{c}\text { Weight } \\
\text { Before } \\
\text { placing in } \\
\text { Soak } \\
\text { Solution } \\
2 \\
\end{array}$ & $\begin{array}{c}\begin{array}{c}\text { Time in } \\
\text { Soak } \\
\text { Solution }\end{array} \\
\\
3 \\
\end{array}$ & 4 & $\begin{array}{c}\text { Weight } \\
\text { after } \\
\text { Solution } \\
\text { Soak } \\
5 \\
5\end{array}$ & $\begin{array}{c}\text { Photograph } \\
\text { Identification } \\
\text { (Magnification } \\
\text { and Distance) } \\
6\end{array}$ \\
\hline 1 & 74,2255 & 10 & $88 \mathrm{C}$ & 74.1880 & Pluto 3,4 \\
\hline 2 & 74.1880 & 10 & 866 & 74,1563 & $2 \mathrm{mill}$ \\
\hline 3 & 74.1563 & 10 & $88 \mathrm{C}$ & 74.1271 & \\
\hline 4 & 74.1271 & 10 & $87 c$ & 784.0972 & D/a, then Ll 3 \\
\hline 5 & 74.0972 & 10 & 890 & 14.0554 & $17+18$ \\
\hline & & & & & \\
\hline & & & & & \\
\hline & & & & & \\
\hline & & & & & \\
\hline & & & & & \\
\hline & & & & & \\
\hline & & & & & \\
\hline & & & & & \\
\hline & & & & & \\
\hline & & & & & \\
\hline & & & & & \\
\hline & & & & & \\
\hline & & & & & \\
\hline & & & & & \\
\hline & & & & & \\
\hline & & & & & \\
\hline & & & & & \\
\hline & & & & & \\
\hline & & & & & \\
\hline & & & & & \\
\hline & & & & . & \\
\hline & & & & & \\
\hline & & & & & \\
\hline & & & & & \\
\hline & & & & & \\
\hline & & & & & \\
\hline & & & & & \\
\hline & & & & & \\
\hline
\end{tabular}




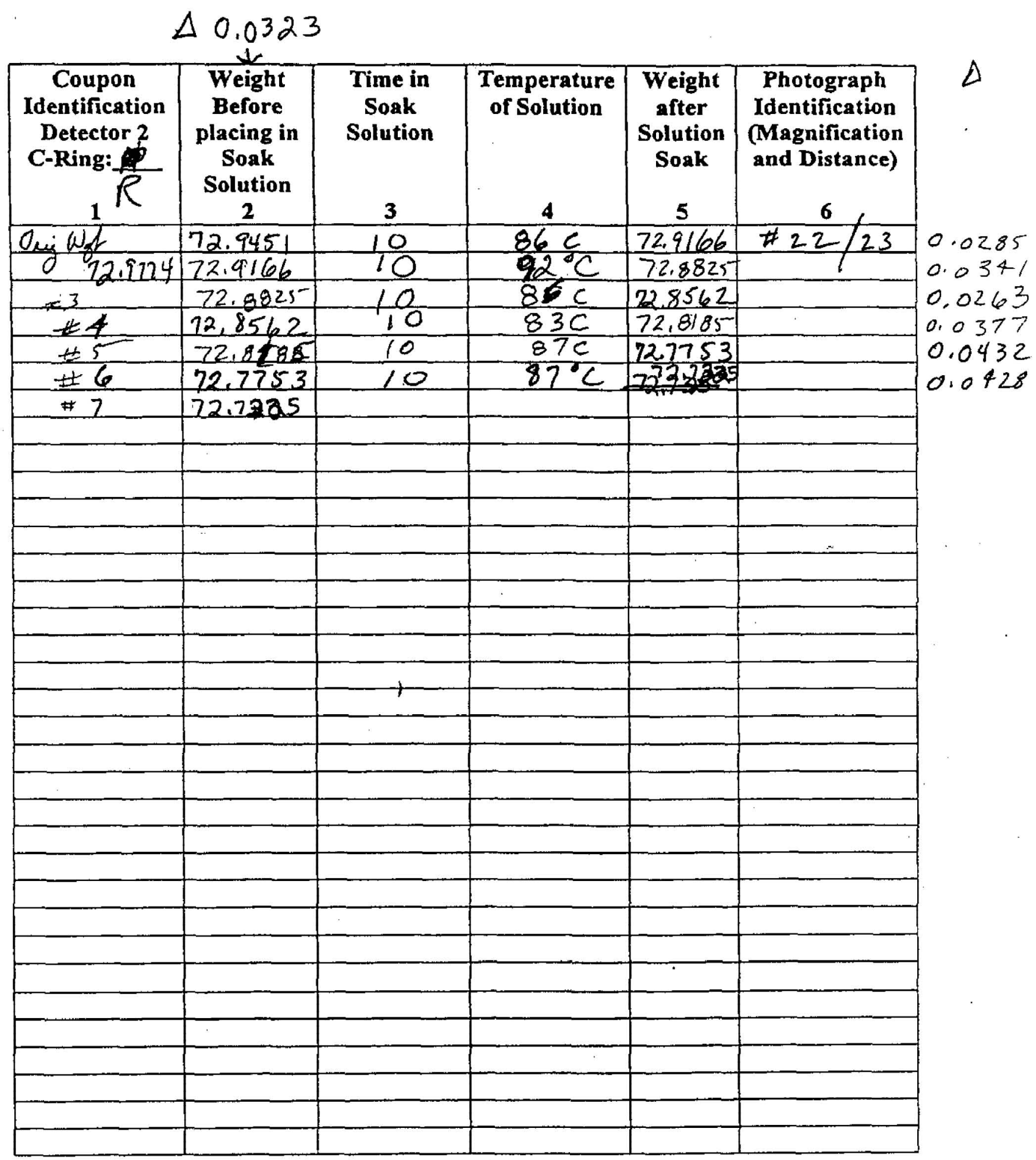

Check Weights

$$
\begin{aligned}
1 g & =1.0000 g \\
5 g & =5.0001 g \\
10 g & =10.0002 g \\
50 g & =50.0003 g \\
100 g & =100.0005 g
\end{aligned}
$$




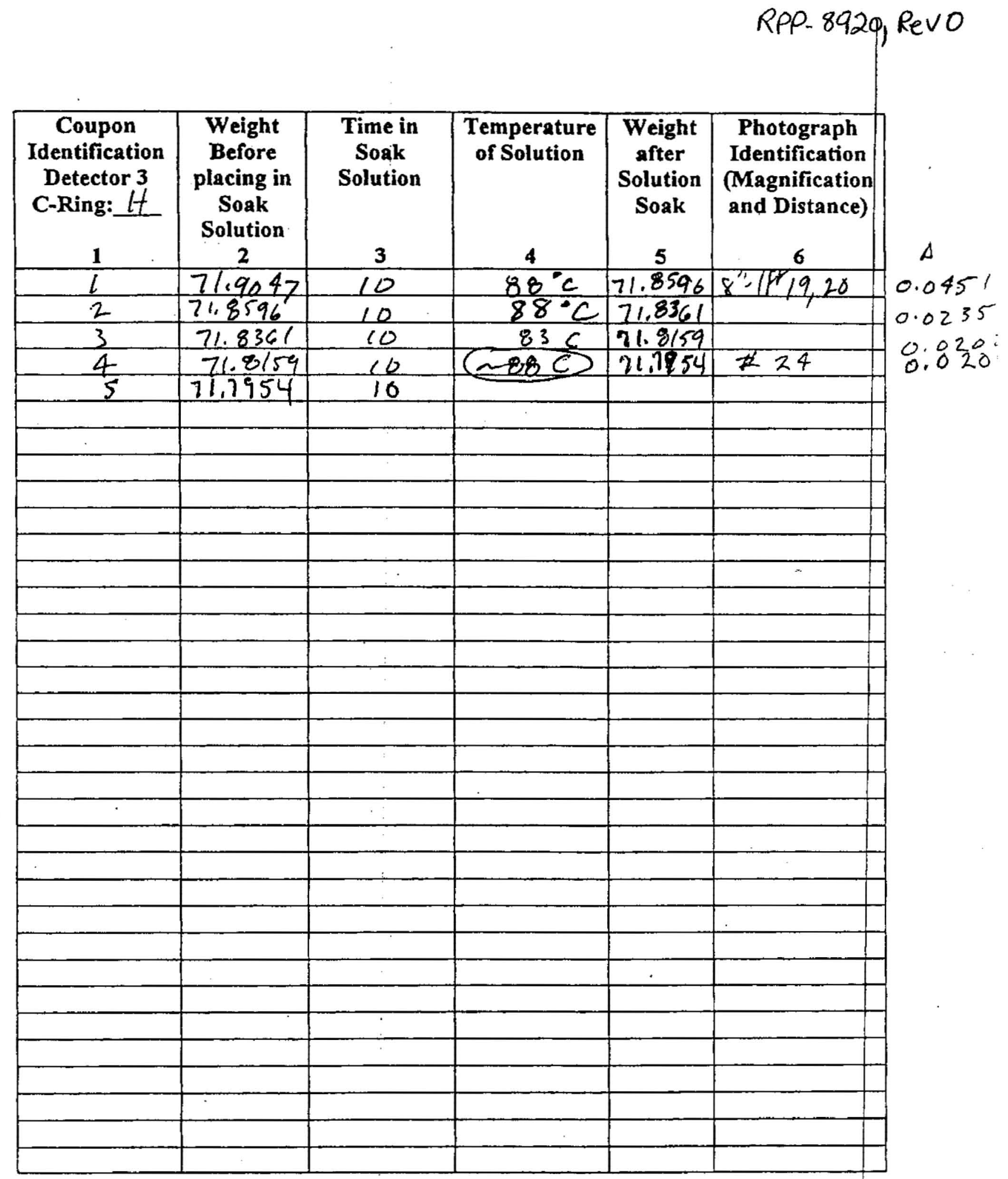

更
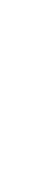

.




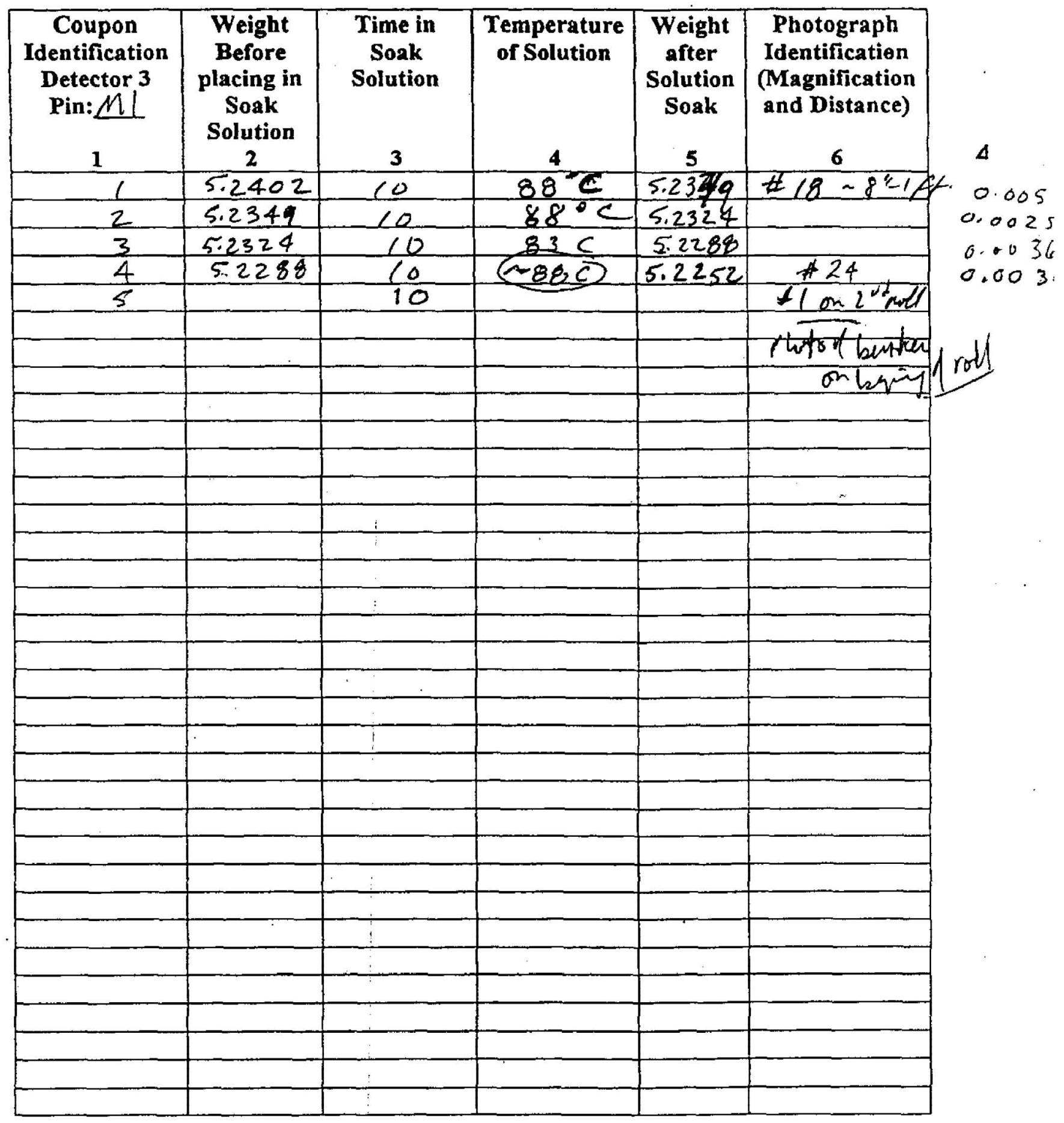




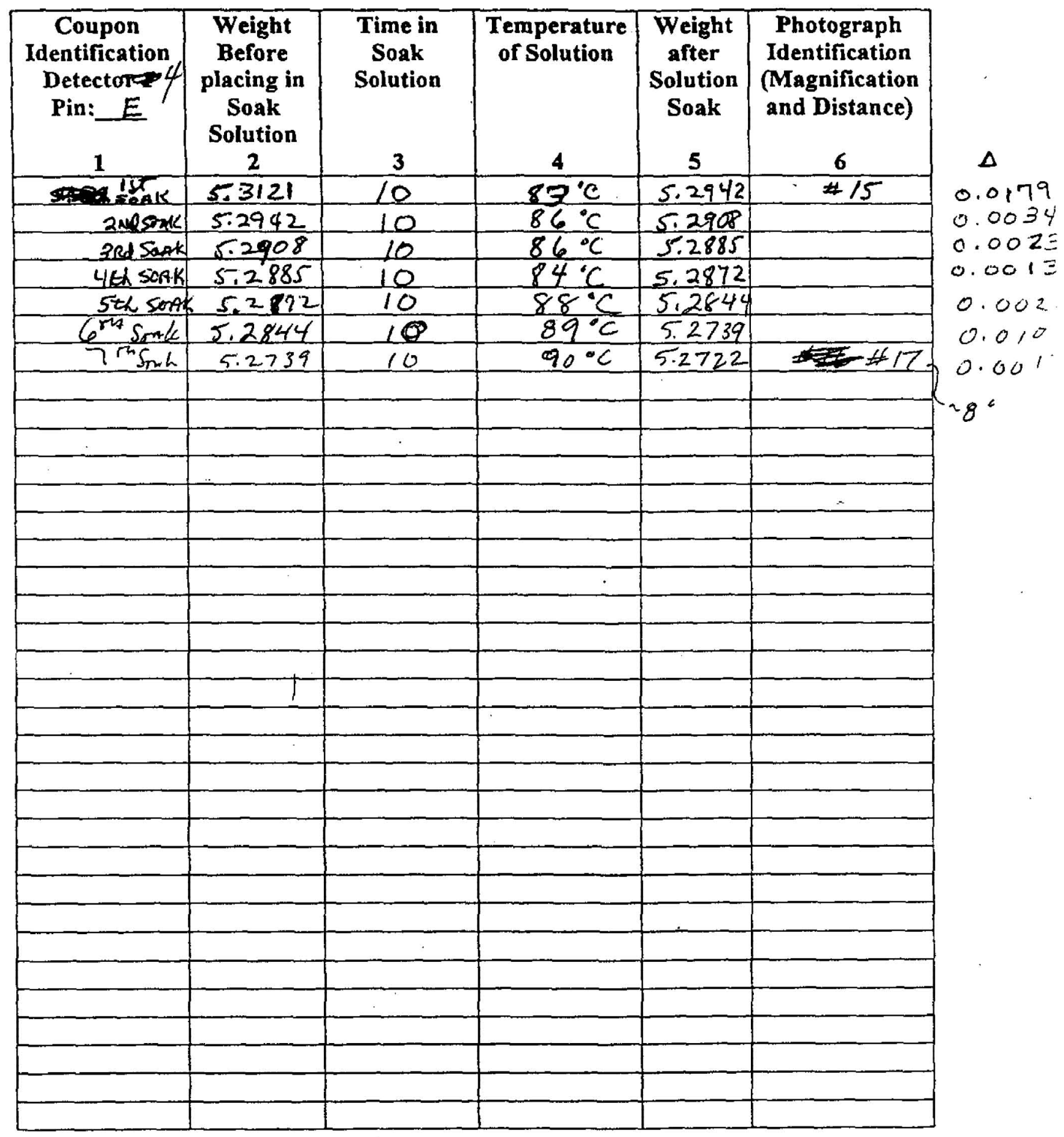




\section{cus ont Tnere}

APPENDIX D (Data Sheets)

\begin{tabular}{|c|c|c|c|c|c|c|}
\hline $\begin{array}{c}\text { Coupon } \\
\text { Identification } \\
\text { Detector } 4 \\
\text { C-Ring: } 8 \\
1\end{array}$ & $\begin{array}{l}\text { Weight } \\
\text { Before } \\
\text { placing in } \\
\text { Soak } \\
\text { Solution } \\
2\end{array}$ & $\begin{array}{l}\text { Time in } \\
\text { Soak } \\
\text { Solution }\end{array}$ & $\begin{array}{c}\text { Temperature } \\
\text { of Solution }\end{array}$ & $\begin{array}{c}\text { Weight } \\
\text { after } \\
\text { Solution } \\
\text { Soak } \\
5\end{array}$ & $\begin{array}{c}\text { Photograph } \\
\text { Identification } \\
\text { (Magnification } \\
\text { and Distance) } \\
6 \\
6 \text { ohth }\end{array}$ & $\Delta$ \\
\hline & 92.6363 & (1) & $89^{\circ} \mathrm{C}$ & 72.6089 & $19 \simeq 16$ & 0.0278 \\
\hline 2 & 72.6089 & 10 & $88 \mathrm{C}$ & 72.5910 & & 0.0175 \\
\hline 3 & 72,5910 & 10 & $89^{\circ} \mathrm{c}$ & 22.5688 & & 0.0222 \\
\hline 4 & 72.5688 & 10 & $85 \cdot c$ & 72.5518 & & 0.0170 \\
\hline 5 & 72.5512 & 10 & $81^{\circ} \mathrm{C}$ & 72.361 & & 0.0151 \\
\hline 6 & 72.5361 & 10 & $83^{\circ} \mathrm{C}$ & 72.5275 & & 0.0086 \\
\hline 7 & 72.5275 & 10 & $81^{\circ} \mathrm{C}$ & 72.5011 & & 0.0226 \\
\hline 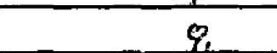 & 725049 & 10 & $84 c$ & 224723 & & $0.03 ? 6$ \\
\hline 9 & 72.4723 & 10 & $84 c$ & 22.4515 & & 0.0208 \\
\hline 10 & 72.4515 & 10 & $85 c$ & $72 .+294$ & $\pm 10 \simeq 1 \#$ & 0.0221 \\
\hline il & 72.4294 & 10 & $90^{\circ} \mathrm{C}$ & 72.3749 & 11012 & 0.054 \\
\hline
\end{tabular}

$373-1189$

$0.88 M$

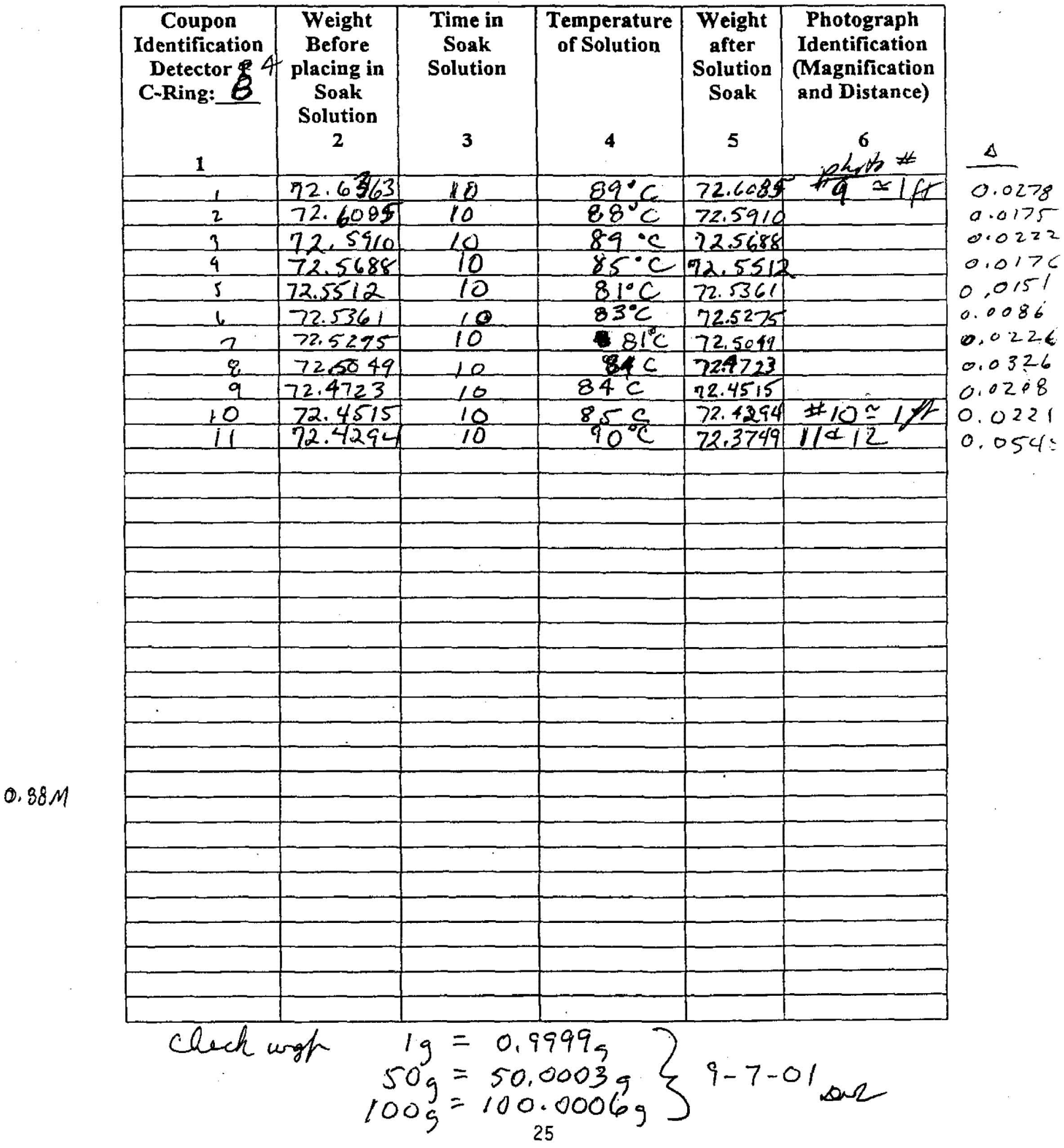




\begin{tabular}{|c|c|c|c|c|c|c|c|}
\hline \multirow{31}{*}{ nate gat anne } & $\begin{array}{c}\text { Coupon } \\
\text { Identification } \\
\text { Detector } \\
\text { C-Ring: C } \\
1\end{array}$ & $\begin{array}{c}\text { Weight } \\
\text { Before } \\
\text { placing in } \\
\text { Soak } \\
\text { Solution } \\
2 \\
\end{array}$ & $\begin{array}{c}\begin{array}{c}\text { Time in } \\
\text { Soak } \\
\text { Solution }\end{array} \\
\\
3 \\
\end{array}$ & $\begin{array}{c}\text { Temperature } \\
\text { of Solution }\end{array}$ & 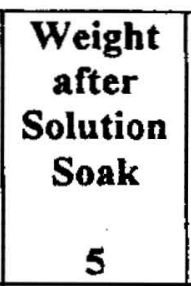 & $\begin{array}{c}\text { Photograph } \\
\text { Identification } \\
\text { (Magnification } \\
\text { and Distanee) } \\
6 \\
6\end{array}$ & \multirow{31}{*}{$\begin{array}{c}\Delta \\
0.0381 \\
0.0303 \\
0.0389 \\
0.0450 \\
0.0215 \\
0.0392 \\
0.0403 \\
0.0402 \\
0.0259\end{array}$} \\
\hline & $1 S T$ coste & 73.4756 & 10 & $83^{\circ} \mathrm{C}$ & 73,4375 & $\pm 13 * 14$ & \\
\hline & 2Ne Sonk & 73.4375 & 10 & $87^{\circ} \mathrm{C}$ & 73.4072 & & \\
\hline & 3red SoAk & 73.4072 & 10 & $87^{\circ} \mathrm{C}$ & 73.3683 & & \\
\hline & $4 \in h$ soak & 73.3683 & 10 & $84^{\circ} \mathrm{C}$ & 73.3233 & & \\
\hline & 5 th SOAK & 73.3233 & 10 & $83^{\circ} \mathrm{C}$ & 73,3018 & & \\
\hline & $60^{m}$ sart & 73.3018 & 10 & $88^{\circ} \mathrm{C}$ & 73.2626 & & \\
\hline & $7^{2}-s_{x} k$ & 73.2626 & 10 & $87^{\circ} \mathrm{C}$ & 73.2124 & & \\
\hline & $8^{n}$ & 73.2224 & 10 & $82 \cdot C$ & 73.19697 & $\$ 16 \sim 8 "$ & \\
\hline & & & & & & & \\
\hline & & & & & & & \\
\hline & & & & & & & \\
\hline & & & & & & & \\
\hline & & & & & & & \\
\hline & & & & & & & \\
\hline & & & & & & & \\
\hline & & & & & & & \\
\hline & & & & & & & \\
\hline & & & & & & & \\
\hline & & & & & & & \\
\hline & & & & & & & \\
\hline & & & & & & & \\
\hline & & & & & & & \\
\hline & & & & & & & \\
\hline & & & & & & & \\
\hline & & & & & & & \\
\hline & & & & & & & \\
\hline & & & & & & & \\
\hline & & & & & & & \\
\hline & & & & & & & \\
\hline & & & & & & & \\
\hline
\end{tabular}

\section{.}

(1)

RPP-8920, ReVO

(1)

